\title{
Influence of carbonation on the resistance of concrete structures to chloride penetration and corrosion
}

\author{
Abbas S. AL-Ameeri ${ }^{1,2}$, M. Imran Rafiq ${ }^{1}$ and Ourania Tsioulou ${ }^{1}$ \\ ${ }^{1}$ School of Environment and Technology, University of Brighton, Brighton, UK \\ ${ }^{2}$ Engineering College, University of Babylon, Babylon, Iraq
}

\begin{abstract}
Chloride-induced corrosion of steel rebar embedded in concrete is one of the major concerns influencing the durability of reinforced concrete structures. It is widely recognized that the carbonation in concrete affects the chloride diffusivity and accelerates the chloride-induced reinforcement corrosion. However, only very limited studies have dealt with this issue in the literature. The presence of service load related cracks also affects the reinforcement corrosion. This study aims to investigate the potential impact of concrete carbonation on the chloride penetration resistance, and degree of corrosion, in RC structures subjected to service related microcracks.

The experimental programme involves casting of concrete prisms $(100 \times 100 \times 500 \mathrm{~mm})$ with different water-cement ratios (w/c) of 0.4, 0.5 and 0.6 and with four different crack widths $(0,0.05-0.15 \mathrm{~mm}, 0.15-0.25 \mathrm{~mm}$ and $0.25-0.35 \mathrm{~mm})$. These samples were exposed initially to accelerated carbon dioxide (CO2) environment and then exposed to the accelerated chloride environment. Carbonation depth, chloride penetration, and the degree of corrosion (using half-cell) were experimentally measured. The results indicated that (i): The depth of carbonation increases with the increase in crack width and $\mathrm{w} / \mathrm{c}$ ratio, (ii) chloride penetration depth in concrete structures increases significantly due to the influence of carbonation and (iii) half-cell corrosion potential increases significantly when carbonated concrete samples are exposed to the chloride environment relative to the uncarbonated concrete samples.
\end{abstract}

\section{Introduction}

Carbon dioxide and chloride ion attack seem to be significant factors which affect the sustainability of concrete structures. Furthermore, the temperature and relative humidity affect the penetration of chloride and sulfate in concrete structures. As a result, the diffusivity of carbon dioxide and chloride have a significant impact on corrosion in concrete structures $[1,2]$. This study aims to investigate the influence of carbonation on the penetration of chloride in concrete and its degree of corrosion. Chloride ions may be transferred into concrete from external sources such as de-icing salt, seawater and groundwater, and internal sources through contaminants in concrete such as marine aggregate and chemical admixtures containing chloride ions [3].

The diffusivity of $\mathrm{CO}_{2}$ in concrete leads to changes in the mineralogical composition (due to carbonation) of concrete and has the potential to reduce the $\mathrm{pH}$ of the pore water in concrete. It may also break down the chloride binding (calcium chloroaluminate), which free up more chloride leading to the deeper penetration of chloride in the concrete. It is a result of the reaction between one of the cement components, namely tricalcium aluminate (C3A) and chloride ions within the pore water in concrete [4]. Carbonation is a significant factor in reducing the $\mathrm{pH}$ and liberation of bound chlorides for cement mortar samples [5].

Cracks in concrete structures are expected due to its weak tensile strength. Cracks can be either non-structural or structural. Structural cracks tend to be wider (>0.1 $\mathrm{mm}$ ) while non-structural cracks are commonly finer. Structural cracks often result from one, or a combination, of the following: insufficient reinforcement, low strength of concrete, excessive loading magnitude or frequency, impact loading, permanent actions such as foundation settlement, creep, etc. While, the non-structural cracks may occur due to physical impact (shrinkable aggregate, drying shrinkage), chemical effect (carbonation shrinkage and alkali -silica reaction) and thermal impact (expansion/contraction due to external temperature variation and freeze and thaw cycle) [6,7]. The cracks may also be the result of deterioration and loss of durability of material or are worsened due to the degradation of material. The durability of concrete structures is controlled by their capacity to delay the transport of ions and harmful fluids inside the concrete. The transport of chloride within uncracked concrete is said to be a combination of the concentration gradient (diffusion), the pressure gradient (permeation) and capillary sorption $[3,8]$. The cracks in concrete introduce an additional factor within the transport properties of concrete, namely the permeability of concrete, which is likely to significantly increase the transport of chloride ions inside concrete [9]. Park et al. [10] found the chloride diffusion coefficient in concrete increases 24 times for crack width of $0.1 \mathrm{~mm}$ and 145 times for crack width of $0.4 \mathrm{~mm}$, when compared with the un-cracked concrete. These results are not fully in agreement with 
the results obtained in $[9,11]$ due to natural formation of cracks in the sample (width, depth and tortuosity) or the method of assessing the diffusion coefficient of chloride.

The studies of durability assessment in literature, such as corrosion initiation, often excludes the effect of carbonation and cracks, voids and defects in concrete, thereby their effectiveness in predicting the durability of concrete structures is reduced [11]. Therefore, it is important to investigate the influence of carbonation and service cracks on the penetration of chloride and the degree of corrosion. Moreover, carbonation and chloride negatively affect the passive protective film (PPF) of steel reinforcement in concrete structures [1], which accelerates the corrosion of reinforced concrete structures $[3,13]$. The focus of this study is to examine the effect of carbonation in reinforced concrete samples on the penetration of chloride and degree of corrosion in cracked and un-cracked concrete samples.

\section{Experimental work}

\subsection{Materials and concrete mix design}

Portland limestone cement (CEM II/A-LL 32,5R) with a specific gravity of 3.05 was used in this study. Chemical and physical properties of the cement comply with BS EN 197- 1: 2011 [14].

Natural sand was used as fine aggregate (particle size $<5 \mathrm{~mm}$ ), and the coarse aggregate used was crushed gravel with the size ranging from $5-14 \mathrm{~mm}$. The grain size distribution, and maximum chloride and sulfate content within the aggregates comply with BS 882:1983 [15]. Deformed or ribbed steel (B500A) (8mm) with mechanical properties compliant with BS 4449:2005+A2:2009 [16] was used to reinforce the concrete prisms to achieve the controlled crack widths in the samples, and to investigate the corrosion condition.

Three different w/c ratios were used to investigate their effects on the penetration of carbonation and chlorides. The Building Research Establishment (BRE) method [17] was used for concrete mix designs that are shown in Table 1.

Table1 Concrete mixes designs used in this study.

\begin{tabular}{|l|c|c|c|c|c|}
\hline \multirow{2}{*}{$\begin{array}{l}\text { Mix } \\
\text { symbol }\end{array}$} & \multicolumn{5}{|c|}{ Content per unit volume of concrete $\left(\mathrm{kg} / \mathrm{m}^{3}\right)$} \\
\cline { 2 - 6 } & w/c & Cement & Water & Sand & Gravel \\
\hline M 0.4 & 0.4 & 513 & 205 & 653 & 980 \\
\hline M 0.5 & 0.5 & 410 & 205 & 711 & 1023 \\
\hline M 0.6 & 0.6 & 350 & 205 & 711 & 1041 \\
\hline
\end{tabular}

\subsection{Specimen Geometry}

Three $100 \mathrm{~mm}$ cube specimens were used to establish the compressive strength of concrete, porosity and depth of carbonation measurements. Reinforced concrete prisms of $100 \times 100 \times 500 \mathrm{~mm}$ were used to measure the depth of carbonation (DoC), chloride penetration and corrosion condition (using half-cell corrosion potential) in both the cracked and un-cracked specimens. A deformed steel bar (B500A) of $8 \mathrm{~mm}$ diameter was located at a cover depth of $2 \mathrm{~cm}$ to reinforce the concrete prisms to achieve the controlled crack sizes within the samples and to investigate the half-cell corrosion potential. The method of filling and preparation of moulds, compaction and levelling the surface of concrete, curing and transporting of samples were in accordance with BS EN 12390 2:2009 [18]. Samples were cast in two layers and each layer was vibrated to achieve homogenous concrete. The specimens were demoulded and cured using tap water until the time of testing, or exposure to $\mathrm{CO}_{2}$ environment condition at the age of 28 days.

\subsection{Specimen conditioning}

The main objective of this study was to investigate the effect of carbonation depth on the chloride penetration and corrosion condition for different properties of concrete and crack width in concrete structures. The flexural method was used to induce the cracks in concrete samples as shown in Fig.1. In addition to the control samples (no cracks), three different crack width ranges, (0.05-0.15mm, $0.15-0.25 \mathrm{~mm}$ and $0.25-0.35 \mathrm{~mm})$ were examined. The crack width was measured using a microscope meter with an accuracy of $0.01 \mathrm{~mm}$ (Fig. 2).

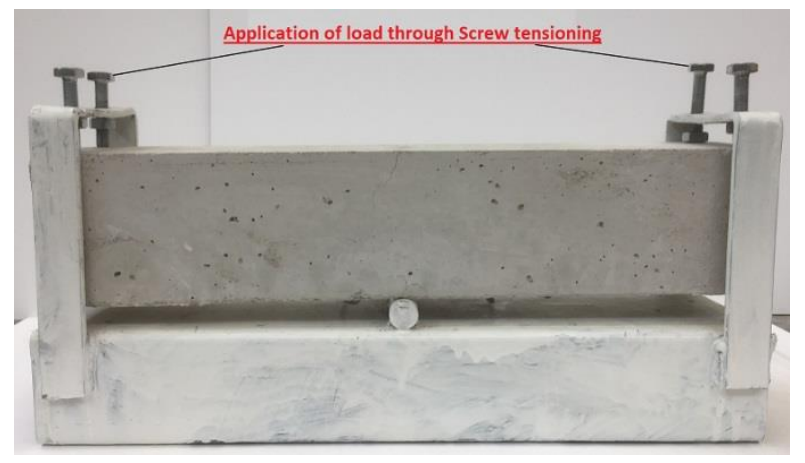

Fig. 1. Method for cracking in the prism samples

In this study, one face of the specimens was exposed to accelerated environment conditions whereas the other faces were sealed using coats of water-based alkyl polysiloxane resin. The control samples were exposed to a chloride fog environment (with $5 \% \mathrm{NaCl}$ ) within a Cyclic Chloride Test (CCT) chamber for 17 weeks in total.

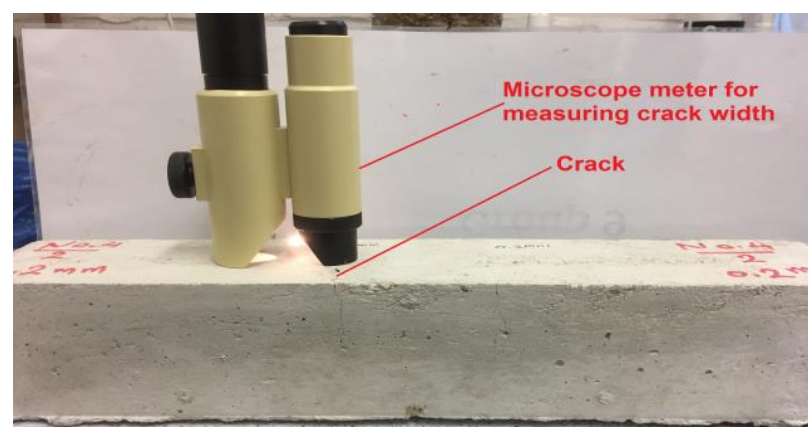

Fig.2. Microscope meter to measure the crack width 
The rest of the samples were taken out of the CCT chamber after 10 weeks of chloride exposure and were exposed to $\mathrm{CO}_{2}$ concentration of $5 \%$ within a $\mathrm{CO}_{2}$ chamber (at a temperature of $25^{\circ} \mathrm{C}$ and relative humidity of $65 \%$ ) for 5 weeks before returning them back in the CCT chamber (chloride exposure) for the remaining 7 weeks.

\subsection{Testing Methodologies}

The compressive strength, ultra-sonic pulse velocity, porosity, depth of carbonation (DoC), chloride penetration, and half- cell potential were carried out for this study. Porosity and compressive strength test were conducted according to ASTM C642:2013 [20] and BS EN 12390-3:2000 [21] respectively. The chloride penetration depth was measured by splitting the conditioned samples into two parts (using a compression testing machine) and spraying $0.1 \%$ silver nitride solution in accordance with [22,23]. The silver nitrate solution reacts with chloride ions to form silver chloride, changing the colour of the concrete surface hence the depth of chloride penetration can be measured [22,23]. Three specimens were tested for every case and an average value is reported here.

In order to measure the depth of carbonation, $\mathrm{CO}_{2}$ conditioned samples were split into two parts using a compression testing machine in accordance with AlAmoudi et al. [24]. The first part was sprayed by a solution with one gram of phenolphthalein powder dissolved into a solution of $70 \mathrm{ml}$ and $30 \mathrm{ml}$ of ethanol and deionized water respectively $[25,26]$. The change of colour of the concrete surface was then used to determine the carbonation depth, DoC. The second face of the sample was drilled for control samples and for cracked samples (at the crack location) to collect concrete powder at different depths from the exposed face. Seven depth intervals were adopted in this study; 0-6 mm, 6-12 mm, 12-18 mm, 18-24 mm, 24-30 mm, 30-36 mm and 36-42 mm using dry drilling equipment. The collected concrete powder was then sieved using 150 micro-meter sieves to reduce the amount of coarse grains (obtained due to crushing of aggregates). The powder was then dried in an oven at $50^{\circ} \mathrm{C}$ for 24 hours and kept in sealed plastic bags till tested.

The apparent $\mathrm{pH}$ of the powder was measured by dissolving $1 \mathrm{~g}$ of concrete powder in $20 \mathrm{ml}$ of deionized water. This mixture (powder and water) was stirred vigorously for 30 seconds and left to settle for 24 hours $[27,28]$. A pH meter was used to measure the apparent $\mathrm{pH}$ of this solution in accordance with BS EN ISO 10523:2012 [29]. Three specimens were tested for every case and an average value is reported in the results.

Finally, the corrosion monitoring tests were carried out using non-destructive techniques. These techniques have been utilized to assess the corrosion activity and determine the corrosion condition of the reinforcement. One of the most used electrochemical techniques was used for monitoring the corrosion of steel in concrete, the half-cell potential. The half-cell potential test was performed in accordance with the ASTM C876:2015 [30] and the method proposed by Bouteiller et al., (2012) [31] as shown in Fig.3. Three specimens were tested for each case and the average results of these are reported in the results.

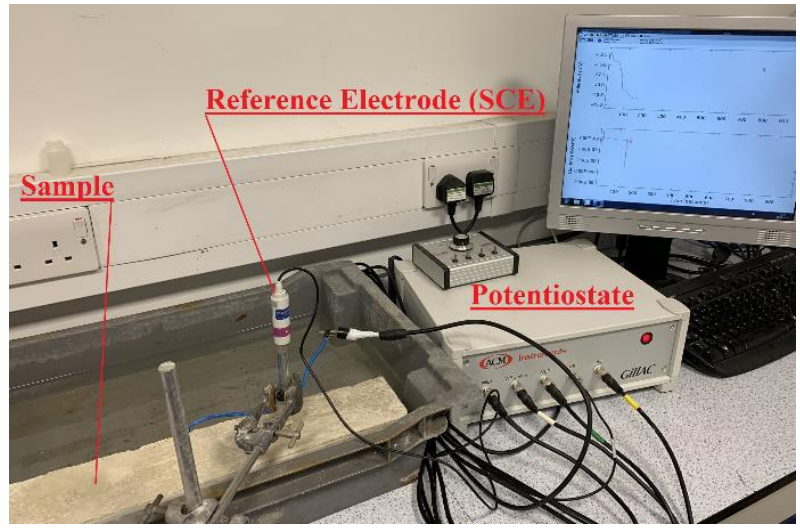

Fig. 3. Potentiostat for half-cell potential measurements.

\section{Results and discussion}

In this section, the results of the experimental work are presented and discussed. These are mainly focused on the impact of carbonation on chloride penetration and corrosion activity for different $\mathrm{w} / \mathrm{c}$ ratio (representing the strength of concrete) and crack widths in concrete samples.

\subsection{Carbonation Depth in Concrete}

The depth of carbonation was established by measuring the depth of carbonation at different points along the sample width and computing the average of these measurements as shown in Fig.4.

The DoC as a function of w/c ratio for the mixes used in this study is shown in Table 2, where M 0.4, M 0.5 and M 0.6 refers to w/c ratio of $0.4,0.5$ and 0.6 respectively. The results illustrate that the carbonation depth increases significantly from the exposed surface with the increase in $\mathrm{w} / \mathrm{c}$ ratio in concrete samples. The percentage increases in DoC for samples having $\mathrm{w} / \mathrm{c}$ ratio 0.5 and 0.6 with respect to the concrete samples with $\mathrm{w} / \mathrm{c}$ ratio of 0.4 are $25 \%$ and $113 \%$ respectively.

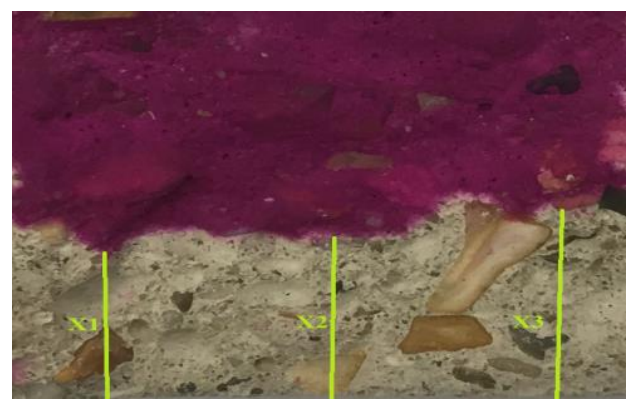

Fig.4. DoC in the concrete sample (M 0.6) exposed to $\mathrm{CO}_{2}$, (5\%) for 5 weeks 
Table 2: Properties of concrete used in the study

\begin{tabular}{|l|c|c|c|}
\hline \multirow{2}{*}{ Property } & \multicolumn{3}{|c|}{ Concrete Mixes } \\
\cline { 2 - 4 } & M 0.4 & M 0.5 & M 0.6 \\
\hline DoC at 5\% $\mathrm{CO}_{2}(\mathrm{~mm}) *$ & 8.0 & 10.0 & 17.0 \\
\hline Coefficient of variation $(\mathrm{COV})$ of DoC & 3.3 & 2.6 & 1.6 \\
\hline Porosity \% * & 10.1 & 11.1 & 11.5 \\
\hline Compressive strength $(\mathrm{MPa}) *$ & 53.2 & 48.1 & 39.7 \\
\hline
\end{tabular}

* These results are the average for three readings

The increase of DoC in concrete mixes as a function of the w/c ratio is a result of the increase in porosity of concrete (also shown in Table 2) and volume of permeable voids, i.e. the pore system of the hardened cement paste $[1,32]$, that helps $\mathrm{CO}_{2}$ to penetrate and react with water to form carbonic acid, the latter then reacts with $\mathrm{Ca}(\mathrm{OH})_{2}$ to form the carbonation products $\left(\mathrm{CaCO}_{3}\right)$.

Fig. 5 presents the results of apparent $\mathrm{pH}$ measurements within the concrete depth, obtained using the dust powder collected at various depths within the concrete samples. The results clearly demonstrate a reduction in apparent $\mathrm{pH}$ within the surface region of concrete (affected by carbonation), which is more pronounced for higher w/c ratios. The increase in w/c ratio lead to an increase the penetration of $\mathrm{CO}_{2}$, which in turn increases the consumption of the alkalinity sources in concrete (i.e. $\mathrm{Ca}(\mathrm{OH})_{2}$ and $\left.\mathrm{C}-\mathrm{S}-\mathrm{H}\right)[27,28]$, hence the $\mathrm{pH}$ levels reduced within the depth of concrete are affected by carbonation.

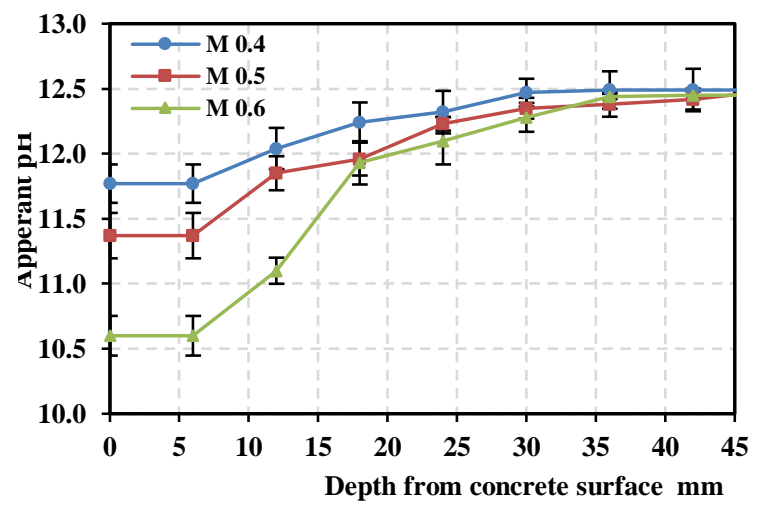

Fig. 5. Apparent $\mathrm{pH}$ profile in concrete due to carbonation

\subsection{Chloride penetration}

Two sets of concrete samples were tested for chloride penetration; the first set was exposed to a $\mathrm{CO}_{2}$ environment in-between the exposure to the chloride fog environment, whilst the second set was just exposed to the chloride fog (control specimen). The difference between the series is the first was exposed to an accelerated $\mathrm{CO}_{2}$ environment, while the second was exposed to a normal $\mathrm{CO}_{2}$ environment and exposure time to $\mathrm{CO}_{2}$ for both was 5 weeks. The silver nitrate $\left(\mathrm{AgNO}_{3}\right)$ colorimetric method was used to measure the chloride penetration depths. The $\mathrm{AgNO}_{3}$ solution spray reacts with chloride ions to form a mixture of silver oxide and silver chloride that precipitates on the concrete surface and changes colour forming a boundary corresponding to the chloride penetration depth within the concrete specimen. Results for the two sets for different crack widths and w/c ratio are presented in Fig. 6. Key observations from these results are:
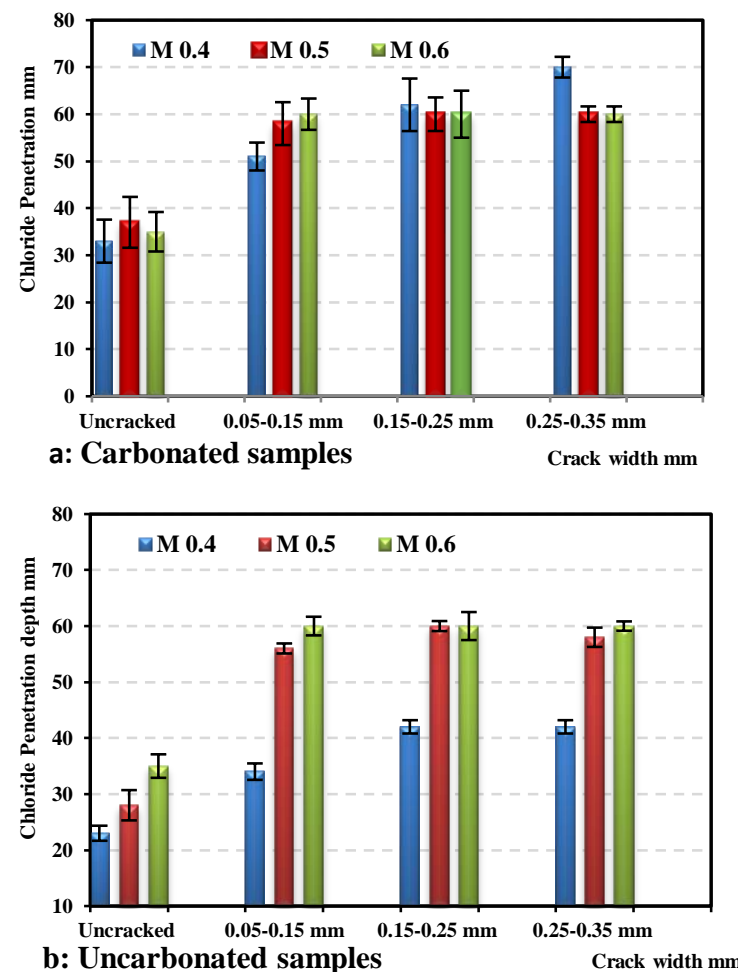

Fig. 6. Effect of w/c ratio and cracked width on chloride penetration $\left(\mathrm{d}_{\mathrm{cl}}-\right)$ for un-carbonated and carbonated samples

(i) The results exhibit higher chloride penetration depths for samples exposed to $\mathrm{CO}_{2}$ environment when compared with the control samples as shown in Fig.7 and Table 3, particularly for the uncracked concrete samples. This can be attributed to the fact that the carbonation reduces the $\mathrm{pH}$ of the pore water in concrete which is a significant factor in liberation of bound chlorides (calcium chloroaluminate) in cement mortar [5] hence increases free chloride concentration and ultimately the penetration depth.

(ii) The results depict an increase in chloride penetration with the increase in w/c ratio for both sets of concrete samples (i.e. with and without carbonation) particularly for the uncracked samples. This can be explained by the fact that the $w / c$ ratio affects the volume of internal voids or porosity in the concrete that in turn affects the chloride ions transport mechanisms in concrete, i.e. diffusion, permeation, sorption and permeability [33]. The percentage increase in chloride penetration depth with the increase in w/c ratio are shown Table 4.

(iii) The chloride penetration depth increases with the crack widths for the all mixes till a threshold crack width is reached, which is estimated from the Fig. 7 to be around $0.1 \mathrm{~mm}$. The crack width and depth affect the transport mechanism of chloride ion into the crack opening since wider cracks may allow the chloride solution to penetrate in the cracks $[34,35]$. The cracks of width less than $0.1 \mathrm{~mm}$ appear to have contributed only through an increase in the rate of transport of chloride 
ions (i.e. increase in permeability and diffusion rates of concrete). However, cracks of width greater than $0.1 \mathrm{~mm}$

(iv) appears to have provided additional surface area (along the crack walls) for the transport of chloride ions into concrete. Hence, an increase in chloride penetration perpendicular to the crack walls can also be observed (Fig. 8), which is similar to the chloride penetration profile from the surface of an uncracked concrete. The percentage increase in chloride penetration depth for cracked samples in relation to the uncracked samples are shown in Table 5.

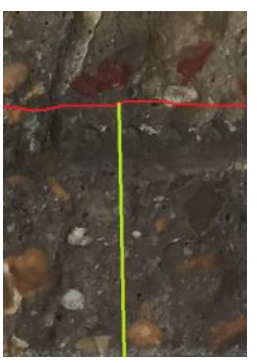

a: $\mathrm{M} 0.4$

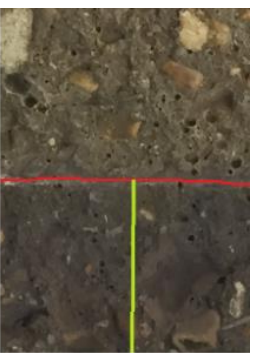

d: $\mathrm{M} 0.4$

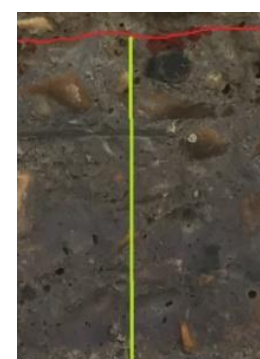

b:M 0.5

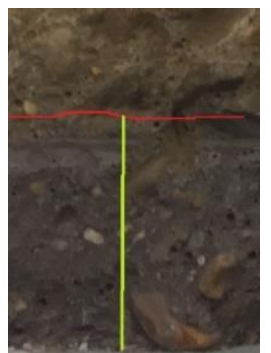

e:M 0.5

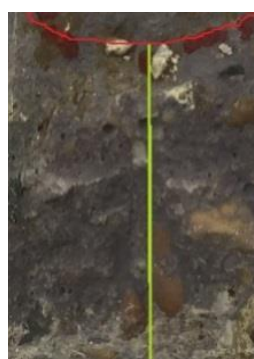

c:M 0.6

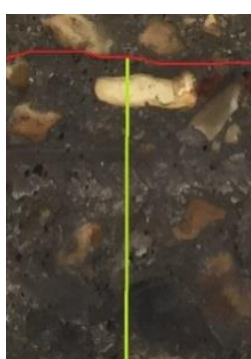

f:M 0.6
Fig. 7. Effect the w/c ratio and carbonation on $\mathrm{d}_{\mathrm{cl}}$ - for Uncracked sample (a, b and c) carbonated samples and $(\mathrm{d}, \mathrm{e}$ and f) Un-carbonated samples

Table 3 Percentage increase in chloride penetration depth in carbonated samples in comparison to un-carbonated samples

\begin{tabular}{|c|c|c|c|c|}
\hline \multirow{2}{*}{ Sample } & \multicolumn{4}{|c|}{ Percentage increase (\%) } \\
\cline { 2 - 5 } & $\begin{array}{c}\text { Un- } \\
\text { cracked }\end{array}$ & $\begin{array}{c}0.05- \\
0.15 \mathrm{~mm}\end{array}$ & $\begin{array}{c}0.15-0.25 \\
\mathrm{~mm}\end{array}$ & $\begin{array}{c}0.25-0.35 \\
\mathrm{~mm}\end{array}$ \\
\hline M 0.4 & 43 & 50 & 48 & 67 \\
\hline M 0.5 & 32 & 4 & 0 & 3 \\
\hline M 0.6 & 0 & 0 & 0 & 0 \\
\hline
\end{tabular}

Table 4 Percentage increase in chloride penetration depth for M 0.5 and M 0.6 samples with respect to M 0.4

\begin{tabular}{|c|c|c|c|c|}
\hline \multirow{2}{*}{ Series } & \multicolumn{4}{|c|}{ Percentage increase (\%) } \\
\cline { 2 - 5 } & $\begin{array}{c}\text { Un- } \\
\text { cracked }\end{array}$ & $\begin{array}{c}0.05-0.15 \\
\mathrm{~mm}\end{array}$ & $\begin{array}{c}0.15-0.25 \\
\mathrm{~mm}\end{array}$ & $\begin{array}{c}0.25-0.35 \\
\mathrm{~mm}\end{array}$ \\
\hline \multirow{2}{*}{$\begin{array}{c}\text { Series 1 } \\
\text { carbonated }\end{array}$} & 12 & 14 & -3 & -14 \\
\cline { 2 - 5 } & 6 & 18 & -3 & -14 \\
\hline $\begin{array}{l}\text { Series 2 } \\
\text { uncarbonated }\end{array}$ & 22 & 65 & 43 & 38 \\
\cline { 2 - 5 } & 52 & 76 & 43 & 43 \\
\hline
\end{tabular}

Table 5 Percentage increase in chloride penetration depth for cracked samples with respect to un-cracked sample

\begin{tabular}{|l|c|c|c|c|}
\hline \multirow{2}{*}{ Series } & \multirow{2}{*}{ Sample } & \multicolumn{3}{|c|}{ Percentage increase (\%) } \\
\cline { 3 - 5 } & & $\begin{array}{c}0.05- \\
0.15 \mathrm{~mm}\end{array}$ & $\begin{array}{c}0.15-0.25 \\
\mathrm{~mm}\end{array}$ & $\begin{array}{c}0.25-0.35 \\
\mathrm{~mm}\end{array}$ \\
\hline \multirow{2}{*}{$\begin{array}{l}\text { Series 1 } \\
\text { carbonated }\end{array}$} & $\mathrm{M} 0.4$ & 55 & 88 & 112 \\
\cline { 2 - 5 } & $\mathrm{M} 0.5$ & 57 & 62 & 62 \\
\cline { 2 - 5 } & $\mathrm{M} 0.6$ & 71 & 71 & 71 \\
\hline \multirow{2}{*}{$\begin{array}{l}\text { Series 2 } \\
\text { uncarbona } \\
\text { ted }\end{array}$} & $\mathrm{M} 0.4$ & 48 & 83 & 83 \\
\cline { 2 - 5 } & $\mathrm{M} 0.5$ & 100 & 114 & 107 \\
\cline { 2 - 5 } & $\mathrm{M} 0.6$ & 71 & 71 & 72 \\
\hline
\end{tabular}

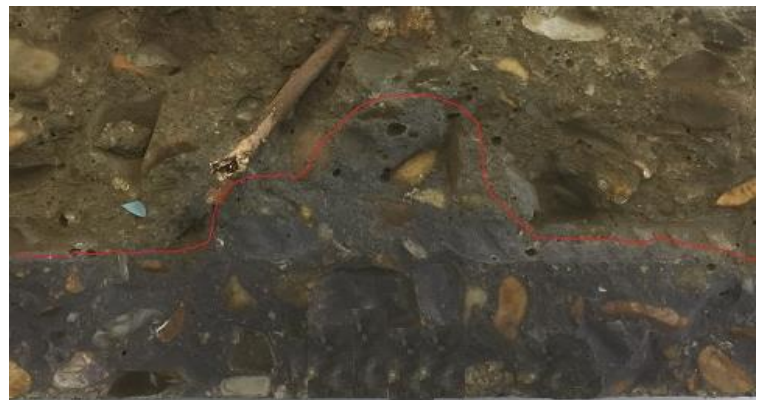

M 0.4-crack width $0.1 \mathrm{~mm}$

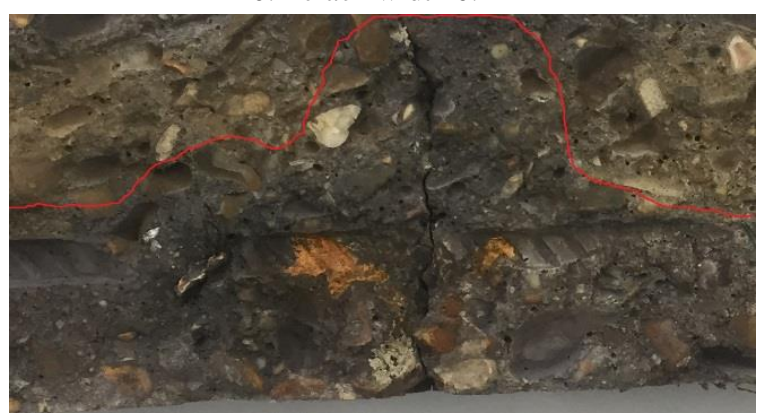

M 0.5-crack width $0.1 \mathrm{~mm}$

Fig. 8. Effect of w/c ratio on the penetration of chloride in the cracked sample

\subsection{Half-cell potential $\left(\mathrm{E}_{\text {corr }}\right)$ results}

The half-cell potential (electrode potential, $\mathrm{E}_{\text {corr }}$ ) measured at various intervals during the exposure of samples to chloride fog, with the aim to detect the transition from passive to active corrosion condition, is presented in Fig. 9. ASTM C876-2015 [30] provides useful interpretation of these results. Half-cell potential values of higher than $-126 \mathrm{mV}$ measured with reference to the saturated calomel electrode (SCE) refers to more than $90 \%$ probability of inactive corrosion (passive state). The potential values in the range of -126 to -276 $\mathrm{mV}$ SCE represents intermediate corrosion risk. Whereas, the potential values more negative than -276 $\mathrm{mV}$ SCE represents a greater than $90 \%$ probability of active corrosion $[31,35]$.

(i) Fig. 9-a, b and c on the next page presents the results of a control specimen (exposure to chloride fog without carbonation) for the three mix designs used in this study. An increase in exposure time of samples to chloride fog monotonically increases the more negative values of the 
electrode potential, i.e. the probability of corrosion increases with the duration of exposure. The electrode potential for many samples had exceeded the threshold potential $(-126 \mathrm{mV}$ SCE) between the passive to intermediate corrosion risk condition after 40 days of exposure. The specimens M 0.5 and M 0.6 attained the potential values that are more negative than $-276 \mathrm{mV}$ SCE after 80 days of exposure for all samples.

(ii) Fig. 9-d, e and f presents the results of carbonated samples for the three mixes used in this study. The exposure of samples to the $\mathrm{CO}_{2}$ environment has a considerable impact on the electrode potential of steel reinforcement. A step change in potential drop can be seen at around 80 days in all carbonated samples (during the period of $\mathrm{CO}_{2}$ exposure), whereas the potential values for samples M 0.4 remained more positive than $-126 \mathrm{mV}$ SCE (> 90\% probability of no corrosion) for the control samples. This suggests that the corrosion conditions have been altered (from passive to active corrosion state) for this concrete mix due to the presence of carbonation.

(iii) The negative values of half-cell potential generally increased with the increase in w/c of concrete (i.e. between M0.4, M0.5 and M0.6 concrete mixes) for both controlled and carbonated specimen. Table 6 details which samples had exceeded the threshold value of more negative than $-276 \mathrm{mV}(>90 \%$ probability of active corrosion), and their respective exposure duration when the threshold was reached.

(vi) The cracks within the samples increases the transport of chloride, accelerating the transition of corrosion from passive to active state. This can be seen from Fig. 9 where the electrode potential value generally increased with the increase in crack width. Hence, the probability of corrosion is proportional to the crack width. For carbonated samples, the impact of crack opening on the potential drop was not clear since samples changed from passive to active corrosion condition during $\mathrm{CO}_{2}$ exposure phase.

\section{Conclusions}

This study explores the impact of carbonation on the chloride penetration, and corrosion condition in concrete samples cracked by service loading. Chloride penetration, carbonation depth, and half-cell corrosion potentials were investigated by using an accelerated environment test programme for $\left(\mathrm{CO}_{2}\right.$ and $\left.\mathrm{Cl}^{-}\right)$. The depth of carbonation, DoC was measured by phenolphthalein Indicator, whereas the chloride front $\left(\mathrm{d}_{\mathrm{cl}}{ }^{-}\right)$was determined by $\mathrm{AgNO}_{3}$ spraying. The half-cell corrosion potential was employed to establish the corrosion condition. DoC using phenolphthalein indicator and $\mathrm{pH}$ investigations made it possible to develop better understanding of the impact of carbonation on chloride penetration and half-cell corrosion potential (corrosion activity). The following conclusions can be drawn from the results;

1- The quality of concrete, i.e. w/c ratio, porosity, and compressive strength affects the depth of carbonation and chloride penetration depths.

2- The chloride penetration significantly increases within the concrete samples exposed to $\mathrm{CO}_{2}$ environment for all mixes used in the study.

3- The half -cell corrosion potential is significantly higher in carbonated samples when exposed to the chloride environment and progressively increases with the exposure time.

4- For concrete specimens exposed to carbonation and chlorides, crack widths influence the corrosion activity and therefore should be considered in service life prediction models. 

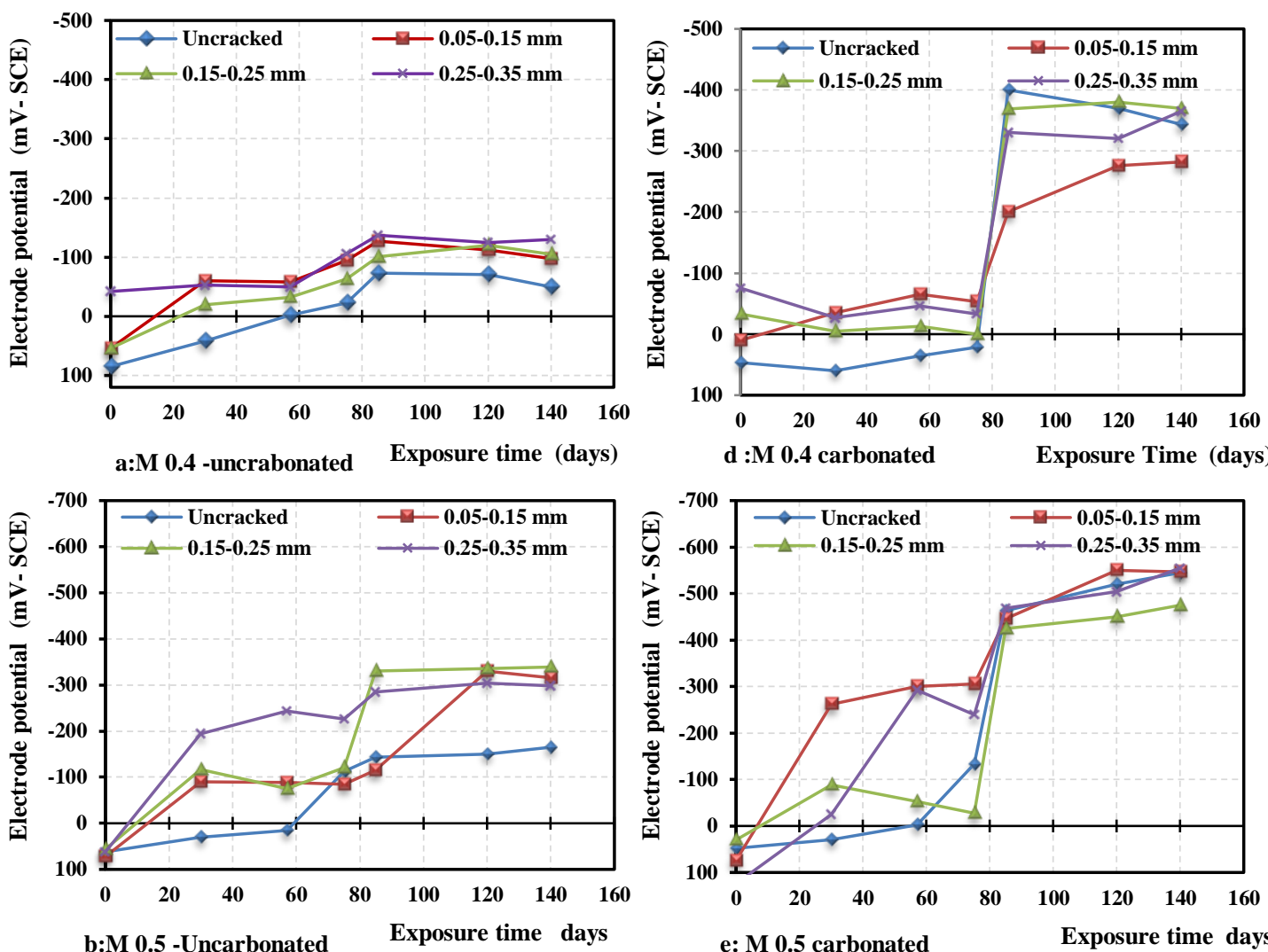

b:M 0.5 -Uncarbonated Exposure time days
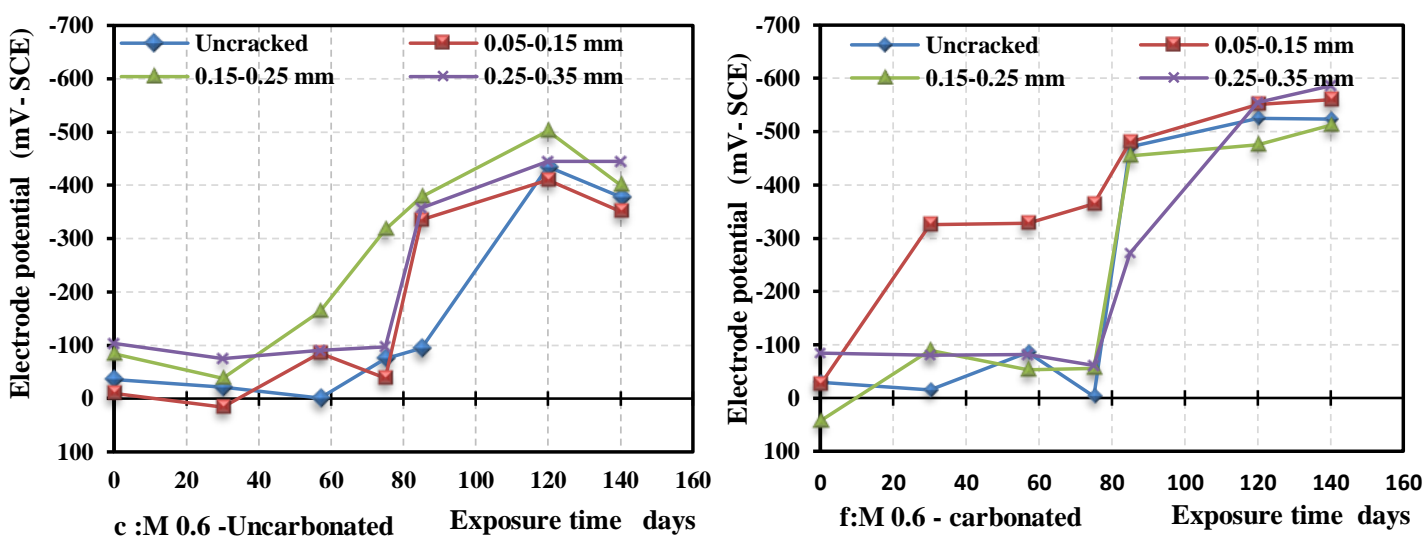

Fig. 9. Effect of $w / c$ and carbonation on half-cell potential of reinforced concrete samples (a,b and c) uncarbonated samples and (d,e and f) carbonated samples

Table 6 Summary of half - cell potential less than $-276 \mathrm{mV}$ and the age

\begin{tabular}{|c|c|c|c|c|c|c|c|c|c|}
\hline \multirow[b]{2}{*}{ Series } & \multirow[b]{2}{*}{ Sample } & \multicolumn{2}{|c|}{ Un-cracked } & \multicolumn{2}{|c|}{$0.05-0.15 \mathrm{~mm}$} & \multicolumn{2}{|c|}{$0.15-0.25 \mathrm{~mm}$} & \multicolumn{2}{|c|}{$0.25-0.35 \mathrm{~mm}$} \\
\hline & & $\begin{array}{c}E_{\text {corr }} \leq- \\
276\end{array}$ & $\begin{array}{l}\text { Age* }^{*} \\
\text { day }\end{array}$ & $\begin{array}{c}E_{\text {corr }} \leq- \\
276\end{array}$ & $\begin{array}{l}\text { Age* } \\
\text { day }\end{array}$ & $\begin{array}{c}\begin{array}{c}E_{\text {corr }} \\
\leq-276\end{array} \\
\end{array}$ & $\begin{array}{c}\text { Age* } \\
\text { day }\end{array}$ & $\begin{array}{c}E_{\text {corr }} \\
\leq-276\end{array}$ & $\begin{array}{c}\text { Age* }^{*} \\
\text { day }\end{array}$ \\
\hline \multirow{3}{*}{$\begin{array}{l}\text { Series1 } \\
\text { carbonated }\end{array}$} & M 0.4 & $\mathrm{Y}$ & 85 & $\mathrm{Y}$ & 85 & $\mathrm{Y}$ & 85 & $\mathrm{Y}$ & 85 \\
\hline & M 0.5 & $\mathrm{Y}$ & 85 & $\mathrm{Y}$ & 85 & $\mathrm{Y}$ & 85 & $\mathrm{Y}$ & 85 \\
\hline & M 0.6 & $\mathrm{Y}$ & 85 & $\mathrm{Y}$ & 30 & $\mathrm{Y}$ & 85 & $\mathrm{Y}$ & 75 \\
\hline \multirow{3}{*}{$\begin{array}{l}\text { Series } 2 \\
\text { Un- } \\
\text { carbonated }\end{array}$} & M 0.4 & - & - & - & - & - & - & - & - \\
\hline & M 0.5 & - & - & $\mathrm{Y}$ & 120 & $\mathrm{Y}$ & 85 & $\mathrm{Y}$ & 85 \\
\hline & M 0.6 & $\mathrm{Y}$ & 110 & $\mathrm{Y}$ & 85 & $\mathrm{Y}$ & 75 & $\mathrm{Y}$ & 80 \\
\hline
\end{tabular}

$\mathrm{E}_{\text {corr }}$ : Half-cell potential is more negative than $-276 \mathrm{mV}$, high probability that corrosion is occurring.

* Age: Time of arrival half-cell potential-SCE is $\leq-276 \mathrm{mV}$.

$\mathrm{Y}$ : Yes, $\mathrm{E}_{\text {corr }} \leq-276 \mathrm{mV}$. 


\section{References}

1. Neville, A.M. Properties of concrete. (Five and Truly Final Edition) London:(2011) Pearson Education Limited.

2. Hussain, S., Rasheeduzzafar, Al-Mu\&am, A. and AlGahtani, A., Factors affecting threshold chloride for reinforcement in concrete. Cem. and Con.Res. J, 25(7) (1995) pp. 1543-1555.

3. Dyer, A., Concrete durability. New York: (2014). Taylor\& Francis Group, LLC.

4. Broomfield, J.P. Corrosion of steel in concrete.2nd edition. London. Taylor \&Francis (2007).

5. Wan, X., Wittmann, F., Zhao, T. and Fan, H., 2013. Chloride content and $\mathrm{pH}$ value in the pore solution of concrete under carbonation. Journal of Zhejiang University-Science A (Appl. Phy. \& Eng.), 14(1), (2013) pp71-78.

6. American Concrete Institute, ACI Committee 224. R, 01. Control of Cracking in Concrete Structures. (2001) Farmington Hills, Mich.: ACI.

7. Concrete Society. Non-structural cracks in concrete, TR 22 (2010) Concrete Society.

8. Morcous, G. and Louis, Z. Maintenance Optimization of Infrastructure Networks using Genetic Algorithms, J of Automat. in Const., 14 (1), (2005) pp 129-142.

9. Sheo-Feng, Z., Chun-Hua, L. and Rong-Gui, L, Experimental determination of chloride penetration in cracked concrete beams. International conference on advanced in engineering, proceeding 24 (2011) pp 380-384

10. Park, S., Kwon, S., and Jung, S., Analysis technique for chloride penetration in cracked concrete using equivalent diffusion and permeation. Const.and Buil. Mat., 29, (2012) pp. 183-192.

11. Kwon S., Na U., Park S.and Jung S., Service life prediction of concrete wharves with early-aged crack: a Probabilistic approach for chloride diffusion. Struct. Saf. J, 31, (2009) pp 75-83.

12. Neville, A.M., Brooks, J.J., Concrete Technology. (Second Edition) London: (2010) Pearson Education Limited.

13. Pacheco, J. and Polder, R. Corrosion initiation and propagation in cracked concrete - a literature review. Proceedings of the 4th International RILEM Ph.D. Workshop, Madrid, Spain (2010).

14. BS EN 197-part 1 (2011). Cement-part 1: Composition, specifications and conformity criteria for common cement.

15. BS.882 (1983). Aggregate from natural sources for concrete. British Standard Institution.

16. BS 4449:2005+A3:(2016). Steel for the reinforcement of concrete. Weldable reinforcing steel. Bar, coil and decoiled product.

17. Teychenné, D.C., E Franklin, R.E. and Erntroy, H. C., Design of normal concrete mixes. Second edition.
Building Research Establishment. Garston, Watford, (1988).

18. BS EN 12390 part- 2:(2009). Testing hardened concrete -; Part 2: Making and curing specimens for strength tests.

19. Al-Samaraai, M.and Raouf, Z. Non-destructive tests for concrete. University of Shariqia, UEA (1999).

20. ASTM C642:2013, Density, Absorption, and Voids in Hardened Concrete.

21. BS EN 12390, part 3:(2000). Testing hardened Concrete Part 3: Compressive strength of test specimens.

22. Yuan.Q. , Shi, C., He, F. Schutter, G. Audenaert, K., and Zheng, K., Effect of hydroxyl ions on chloride penetration depth measurement using the colorimetric method. Cem. and Con. Res. J ,38 (2008) pp1177-1180.

23. He, F., Shi, C., Yuan, Q., An, X. and Tong, B. Calculation of chloride concentration at color change boundary of AgNO3 colorimetric measurement. Cem. and Con. Res. J 41 (2011) pp1095-1103.

24. AL-Amoudi, O., Rasheeduzzafar and Maslehuddin, M. Carbonation and corrosion of rebars in saltcontaminated OPC/PFA concretes. Cem. and Con. Res. J, 21(1991), pp 38-50.

25. BS EN13295:(2004). Products and systems for the protection and repair of concrete structures - Test methods - Determination of resistance to carbonation.

26. DD CEN/TS 12390-10:(2007). Testing hardened concrete. Determination of the relative carbonation resistance of concrete, European Committee for Standardization.

27. Mc Polin, D., Basheer, M., Long, E., Grattan, V. and Sun, T. New Test Method to Obtain pH Profiles due to Carbonation of Concretes Containing supplementary Cementitious Materials, $\mathrm{J}$ of mat. in civil eng., ASCE, 19 November (2007), pp 936-946.

28. Wang, J., Basheer, M., Nanukuttan, S., Long, A., Bai, Y. Influence of service loading and the resulting micro-cracks on chloride resistance of concrete. Const.and Build. Mat., Vol. 108 (2016) pp 56-66.

28. BS EN ISO 10523 (2012). Water quality Determination of $\mathrm{pH}$.

29. ASTM C 876(2015). Half-Cell Potentials of Uncoated Reinforcing Steel in Concrete.

30. Bouteiller, V., C. Cremona, V. Baroghel-Bouny.. Corrosion initiation of reinforced concretes based on Portland or GGBS cement: Chloride contents and electrochemical Cem. and Con. Res , 42(11), (2012) pp1456-1467.

31. Chi, J. M., Huang, R.and Yanlg, C. C. Effect of Carbonation on Mechanical Properties and Durability of Concrete Using Accelerating Testing Method. ; J of Marine Sci. and Tech.y, 10(1),( 2002) pp 14-20. 
32 Basheer, L., J. Kropp and D. J. Cleland. Assessment of the durability of concrete from its permeation properties: a review. Const. and buil. mat., 15(2-3), (2001) pp 93-103.

33. Audenaert, K., G. De Schutter and L. Marsavina. Influence of cracks and crack width on penetration depth of chlorides in concrete. Eur. Journal of env. and civil eng., 13(5), (2009) pp 561-572.

34. Suzuki, K., Ohno, Y., Praparntanatorn, S. and Tamura, H., . Mechanism of Steel Corrosion in Cracked Concrete, Corrosion of Reinforcement in Concrete, Ed. Page, C., Treadaway, K. and Bramforth, P., London: Society of Chemical Industry, (1990) pp. 19-28.

35. Song, H.W and Saraswathy, V. Corrosion Monitoring of Reinforced Concrete Structures - A Review, . Inte.J of Electro chem. Sci. , 2(2007) pp 1-28, 